\title{
A DIAMONDIFEROUS LHERZOLITE FROM THE PREMIER DIAMOND MINE, SOUTH AFRICA
}

\author{
K.S. (Fanus) Viljoen and Rene Dobbe \\ GeoScience Centre, De Beers Consolidated Mines, South Africa
}

\section{INTRODUCTION}

This paper reports on the discovery of a diamondiferous peridotite from the Premier diamond mine. Such xenoliths are surprisingly rare on the Kaapvaal Craton, with 4 specimens having been decribed from Finsch (Shee et al 1982; Viljoen et al 1992), 8 from Roberts Victor (Viljoen et al 1994), and one from Mothae in Lesotho (Dawson and Smith 1975). A number of diamond-bearing peridotitic garnet macrocrysts have also been recognised at the Newlands kimberlite (Daniels et al 1995).

The x-ray diamond recovery circuit (the Sortex Plant) at the Premier diamond mine in South Africa typically generates about 3 specimens of diamond partially enclosed in kimberlite each day. These are sent to the sorthouse at the mine where a small press is used to liberate the diamonds from the kimberlite matrix. Maggie Mahlase, a diamond sorter, recognised the importance of the specimen when crushing revealed numerous diamonds. At least 50 diamonds, ranging in size from less than $1 \mathrm{~mm}$ to approximately $2 \mathrm{~mm}$, are available for study, along with numerous $\mathrm{cm}$-sized fragments of the original xenolith (many of which still contain diamonds in-situ).

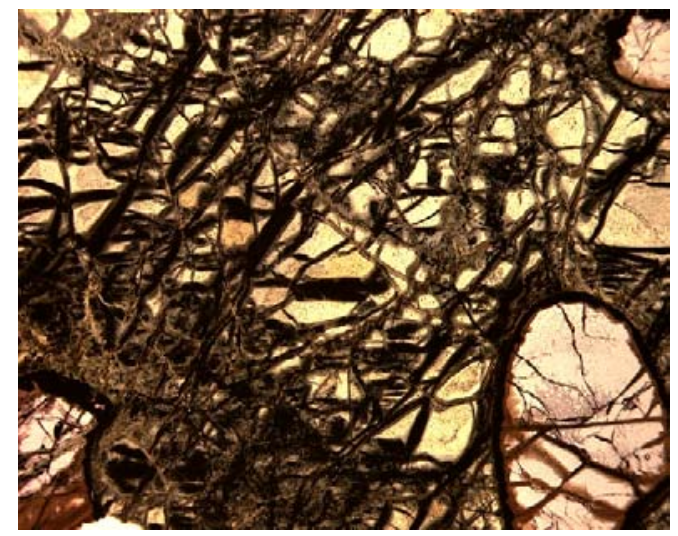

Figure 1: Photomicrograph of the diamond-bearing peridotite from Premier. Rounded garnets are set in a coarse matrix of serpentine pseudomorphs after possible olivine and orthopyroxene.

\section{PETROGRAPHY}

The xenolith is altered with pervasive serpentinisation of constituent minerals (Figure 1). Garnets are generally partially kelyphitised. They range in size up to $2 \mathrm{~mm}$. These occur interstitially with serpentine pseudomorphs after possible olivine and/or orthopyroxene. The pervasive alteration complicates petrography and it is not possible to accurately determine volume percentages of these two minerals, assuming that both are present. Other minerals typical of peridotites such as clinopyroxene and accessory spinel are not seen. The xenolith texture is coarse (i.e. not sheared).

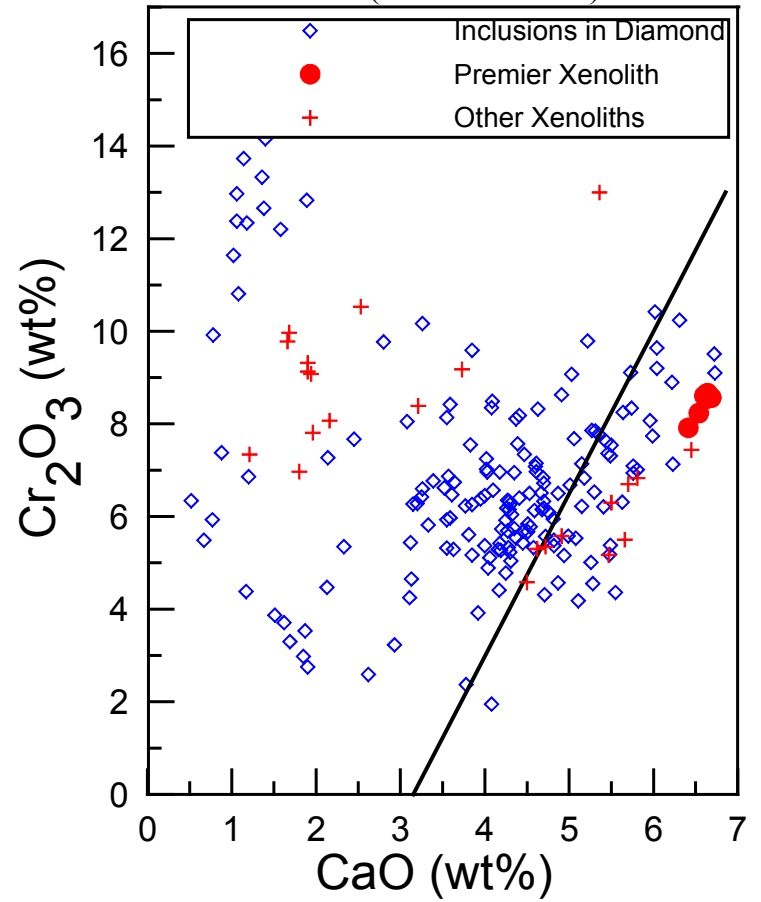

Figure 2: Distribution of $\mathrm{CaO}$ and $\mathrm{Cr}_{2} \mathrm{O}_{3}$ in peridotitic garnets occurring as inclusions in diamonds from Premier as well as the diamond-bearing peridotite from Premier. Also shown are garnets from other diamondbearing peridotites and diamond-bearing macrocrysts in Southern Africa. The Premier xenolith garnets plot within the lherzolite field as defined by the $85 \%$ line of Gurney and Switzer (1973). 


\section{MINERAL CHEMISTRY}

Electron microprobe analysis of the cores of 11 individual garnets show extremely limited chemical variability between grains. They contain, on average, $0.24 \mathrm{wt} \% \mathrm{TiO}_{2}, 8.5 \mathrm{wt} \% \mathrm{Cr}_{2} \mathrm{O}_{3}$ and $6.6 \mathrm{wt} \% \mathrm{CaO}$. The $\mathrm{Cr}$ and $\mathrm{Ca}$ values are consistent with a lherzolitic paragenesis (Figure 2). Garnets occurring as inclusions in diamonds from the Premier Mine (Richardson et al 1993) as well as garnets from diamond-bearing peridotites and diamond-bearing macrocrysts from the Kaapvaal craton are characterised by a range in $\mathrm{Ca}$ compositions, with both Ca-saturated lherzolitic as well as low-Ca harzburgitic varieties represented. Compared to these chemistries the garnets analysed in the present study are quite calcic and compositionally almost at the maximum $\mathrm{CaO}$-limit defined by garnet inclusions in diamonds from Premier.

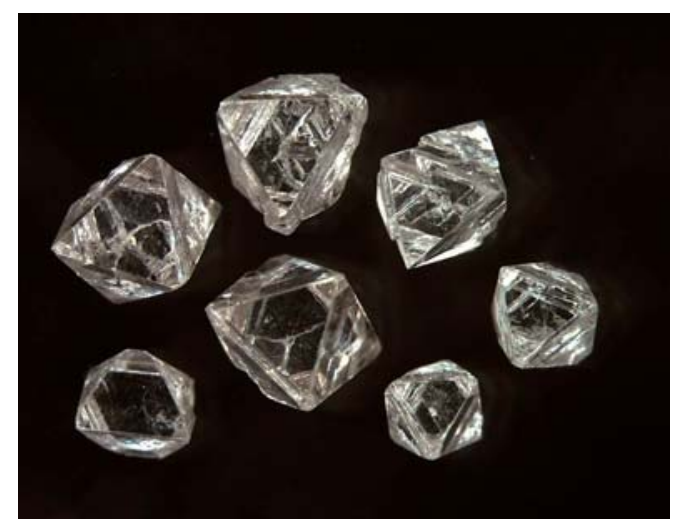

Figure 3: Octahedral diamonds recovered from the Premier xenolith.

\section{DIAMONDS}

All diamonds recovered are colourless. Most crystals are sharp-edged octahedra (Figure 3), some with minor development of the dodecahedral form (this presumably formed on crystals partially protruding from the xenolith which would have been in contact with the molten kimberlite magma). A number of crystals are twinned octahedral macles, while aggregates of two or more octahedra are also common. Mineral inclusions are rare. Where present they are predominantly small black rosettes of sulphide. In one instance a polymineralic (presumably lherzolitic) assemblage of reddish garnet, green clinopyroxene and a colourless mineral is recognised. The xenolith is estimated to contain a minimum of 27700 carat/ton diamond.
Infrared analysis of the xenolith diamonds show nitrogen contents generally lower than $500 \mathrm{ppm}$ and variable nitrogen aggregation state, from $10 \%$ to $80 \%$ of the highly aggregated 'B' form. When plotted on a nitrogen aggregation diagram a well defined trend of increasing nitrogen aggregation state with increasing nitrogen content is observed (Figure 4). This equates to a calculated mantle residence temperature on the order of $1200^{\circ} \mathrm{C}$ at an assumed mantle residence time of 750 My for lherzolitic diamonds at Premier (Richardson et al 1993).

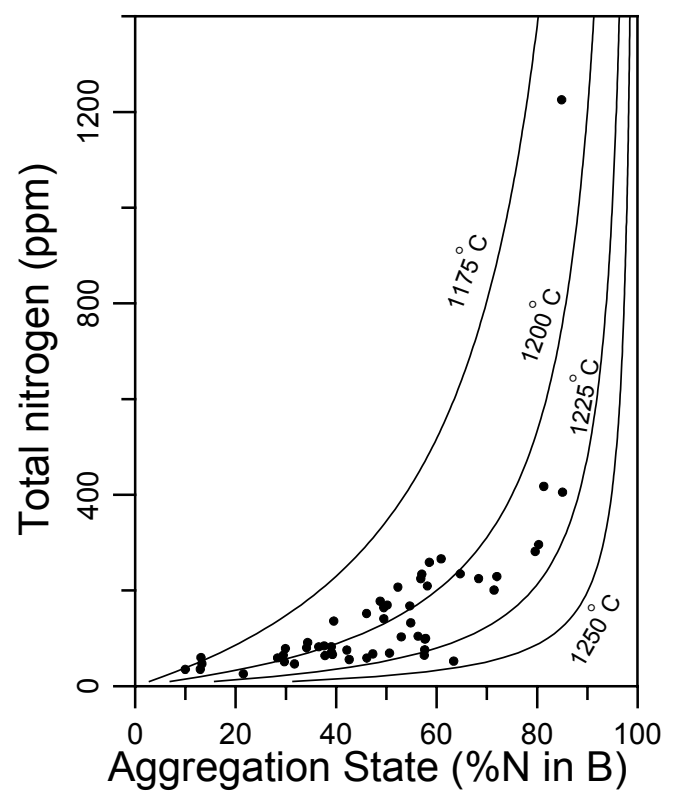

Figure 4: Plot of nitrogen content and aggregation state for diamonds from the Premier xenolith. Isotherms calculated for a mantle residence time of $750 \mathrm{Ma}$.

\section{REFERENCES}

Daniels LRM, Richardson SR, Menzies AH, De Bruin D, Gurney JJ., 1995. Diamondiferous garnet macrocrysts in the Newlands kimberlite, South Africa - Rosetta stones from the Kaapvaal craton: Extended Abstracts $6^{\text {th }}$ International Kimberlite Conference.

Dawson JB, Smith JV., 1975. Occurrence of diamond in a mica-garnet lherzolite xenolith from kimberlite. Nature 254, 580 - 581.

Gurney JJ, Switzer GS., 1973. The discovery of garnets closely related to diamonds in the Finsch pipe. Contrib Mineral Petrol 39, 103 - 116. 
Richardson SH, Harris JW, Gurney JJ., 1993. Three generations of diamonds from old continental mantle. Nature 366, 256 - 259.

Shee SR, Gurney JJ, Robinson DN., 1982. Two diamondbearing peridotitic xenoliths from the Finsch kimberlite, South Africa. Contrib Mineral Petrol 81, 79 - 87.

Viljoen KS, Swash PM, Otter ML, Schulze DJ, Lawless PJ., 1992. Diamondiferous garnet harzburgites from the Finsch kimberlite, Northern Cape, South Africa. Contrib Mineral Petrol 110, 133 $-138$.

Viljoen KS, Robinson DN, Swash PM, Griffin WL, Otter ML, Ryan CG, Win TT., 1994. Diamond- and graphite-bearing peridotite xenoliths from the Roberts Victor kimberlite, South Africa. In: Proceedings of the fifth international kimberlite conference (1991), vol 1, Kimberlites, related rocks and mantle xenoliths. Eds HOA Meyer and $\mathrm{OH}$ Leonardos. Companhia de Pesquisa de Recursos Minerais - Special Publication 1/A Jan/94, Brasilia, 285 - 303.

Contact: KS Viljoen, PO Box 82232, Southdale, 2135, South Africa, E-mail: fanus.viljoen@debeersgroup.com 